\title{
Evaluation of demographic and clinical characteristics of 166 patients with herpes zoster in the Kırșehir region
}

\author{
Kırșehir yöresinde herpes zosterli 166 hastanın klinik ve demografik özelliklerinin \\ değerlendirilmesi
}

\section{Ersoy Acer, ๑ Hilal Kaya Erdoğan, ๑ Ișıl Bulur*, ๑ Emine Müge Acar**}

Eskișehir Osmangazi University Faculty of Medicine, Department of Dermatology, Eskișehir, Turkey

${ }^{*}$ Memorial Șisli Hospital, Clinic of Dermatology, İstanbul, Turkey

${ }^{* *}$ Ahi Evran University Faculty of Medicine, Department of Dermatology, Kırșehir, Turkey

\begin{abstract}
Background and Design: Herpes zoster $(\mathrm{HZ})$ occurs by reactivation of the latent varicella zoster virus at dorsal root ganglia. In the literature, there are studies on socio-demographic and clinical characteristics of patients with $\mathrm{HZ}$ in our country and in the world, however, there has been no study performed in our region. We aimed to evaluate demographic and clinical characteristics of patients with $\mathrm{HZ}$ and to investigate differences and similarities with other epidemiological studies in Turkey and in the world.

Materials and Methods: One hundred sixty-six patients clinically diagnosed with HZ by dermatologists between January 2015 and December 2016 and were followed for 3 months in terms of possible complications were included this study. Demographic and clinical characteristics of the patients were recorded.

Results: The mean age of the patients was $51.48 \pm 21.05$ (1-90) years. Eighty-seven patients were female (52.4\%), 79 were male (47.6\%). Thirteen patients $(7.8 \%)$ were in the pediatric age group $(<18)$. The frequency of patient admission was highest in December and lowest in March. The most frequent locations of the lesions were thoracic (76 patients, 45.8\%) and lumbar (40 patients, 24.1\%) regions. The lesions were on the left side of the body in $96(57.8 \%)$ and right side in $70(42.2 \%)$ patients. The most frequent triggering factor was emotional stress. Post-herpetic neuralgia (27.7\%) was the most frequently seen complication. The most common systemic comorbidity was hypertension. Malignancy was present in only 3 patients (1.8\%).

Conclusion: Our data were highly comparable with other studies. However, occurrence of $\mathrm{HZ}$ mostly during the winter and in the left side of the body was the difference from other studies. We conclude that further country-wide studies with larger number of patients are needed in order to clarify the epidemiological and clinical characteristics of $\mathrm{HZ}$ in our country.
\end{abstract}

Keywords: Epidemiology, herpes zoster, post-herpetic neuralgia, varicella zoster virus

Öz

Amaç: Herpes zoster (HZ) dorsal kök ganglionlarında latent kalan varisella zoster virüsün reaktive olmasıyla ortaya çıkar. Literatürde ülkemizde ve dünyada HZ'nin sosyo-demografik ve klinik özelliklerini değerlendiren çalışmalar vardı ancak bölgemizde yapılan bir çalışma yoktu. Çalışmamızda HZ tanısı konulan hastaların klinik ve demografik özelliklerini incelemeyi ve Türkiye ve dünyadaki diğer epidemiyolojik çalışmalarla benzerlik ve farklııklarını araştırmayı amaçladık.

Gereç ve Yöntem: Ocak 2015-Aralık 2016 tarihleri arasında dermatologlar tarafından HZ tanısı konulan 166 hasta çalışmaya dahil edildi ve olası komplikasyonlar açısından 3 ay boyunca takip edildi. Hastaların demografik ve klinik özellikleri kaydedildi.

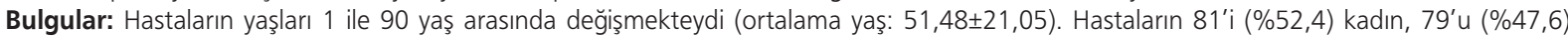
erkekti. Hastaların 13'ü $(\% 7,8)$ pediatrik yaş grubunda $(<18)$ idi. Hasta başvuruları aralık ayında en yüksek, mart ayında en düşük seviyedeydi. En sık etkilenen bölgeler torasik (76 hasta, \%45,8) ve lumbar (40 hasta, \%24,1) idi. Lezyonlar, 96 hastada (\%57,8) vücudun sol tarafında, 70 hastada $(\% 42,2)$ sağ tarafında gözlendi. En sık tetikleyici faktör emosyonel stresdi. En sık görülen komplikasyon postherpetik nevraljiydi (46

Address for Correspondence/Yazışma Adresi: Ersoy Acer MD, Eskişehir Osmangazi University Faculty of Medicine, Department of Dermatology, Eskişehir, Turkey Phone: +90 5067147574 E-mail: ersoyacer@hotmail.com Received/Geliş Tarihi: 15.09.2017 Accepted/Kabul Tarihi: 17.04.2018 ORCID ID: orcid.org/0000-0002-6041-6636

CCopyright 2018 by Turkish Society of Dermatology and Venereology

Turkderm-Turkish Archives of Dermatology and Venereology published by Galenos Yayınevi. 
hasta, \%27,7). En sık görülen sistemik hastalık hipertansiyondu. Sadece 3 hastada (\%1,8) malignite mevcuttu.

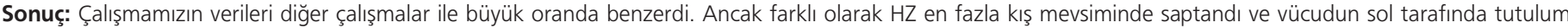

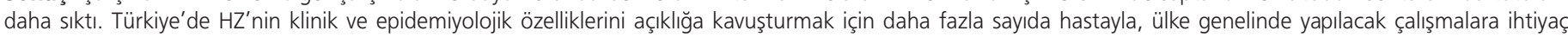
duyulduğunu düşünmekteyiz.

Anahtar Kelimeler: Epidemiyoloji, herpes zoster, postherpetik nevralji, varisella zoster virüs

\section{Introduction}

Varicella zoster virus (VZV) causes chickenpox which is the primary infection and then remains latent at dorsal root ganglia or cranial nerve sensory ganglia. VZV reactivation from latency leads to herpes zoster (HZ). HZ typically occurs as painful, group of vesicles on an erythematous base located on dermatomes ${ }^{1,2}$.

\section{Aim}

There are studies on socio-demographic and clinical characteristics of patients with $\mathrm{HZ}$ in our country and the world. However, there has been no study in our region. We aimed to investigate socio-demographic and clinical characteristics of patients with $\mathrm{HZ}$ and to demonstrate the differences and similarities with other studies.

\section{Materials and Methods}

This study was conducted in our dermatology outpatient clinic. We followed the Helsinki Declaration principles and obtained approval from Ahi Evran University Local Ethics Committee (approval number: 201709/76, 23.05.2017). All patients gave written informed consent. One hundred sixty-six patients, who received the clinical diagnosis of $\mathrm{HZ}$ established by dermatologists between January 2015 and December 2016, were included in this study and were followed for 3 months in terms of possible complications. Patients who refused to participate in the study were excluded. Demographic and clinical characteristics of patients such as age, gender, hospital admission time, location of the lesion, the affected dermatome, triggering factors, accompanying systemic diseases and malignancy, complications, and treatments were recorded. Demographic and clinical characteristics of patients with $\mathrm{HZ}$ were evaluated and differences and similarities with other epidemiological studies in Turkey and in the world, were investigated.

\section{Statistical Analysis}

IBM SPSS Statistics 21.0 program was used for data analyses. Continuous data were presented as \pm standard deviation. Categorical data was presented in percentage (\%).

\section{Results}

One hundred sixty-six $\mathrm{HZ}$ patients were included in the study. $\mathrm{HZ}$ was diagnosed in $0.68 \%$ of patients who were admitted during the study period (24125 patients). The mean age of the patients was $51.48 \pm 21.05$ years (range:1-90 years). Eighty-seven patients were female $(52.4 \%)$ and 79 were male $(47.6 \%)$ and the female-to-male ratio was 1.1 . While 13 patients $(7.8 \%)$ were within the pediatric age group (<18), 153 (92.2\%) were within the adult age group. Most of the patients, both males and females, were in the $6^{\text {th }}$ and $7^{\text {th }}$ decades of life (Figure 1).

The rate of hospital admission was highest in December (14.5\%) and lowest in March (3.0\%) (Figure 2). The highest number of patients was diagnosed in the winter (33.7\%) and lowest in spring (16.8\%). The most common locations of the lesions were thoracic (45.8\%) and lumbar (24.1\%) regions in all patients (Table 1). While thoracic (45.1\%) and lumbar $(25.5 \%)$ involvement was the most common in adults, thoracic (53.8\%) and lower extremity (15.4\%) involvement was the most frequent in the pediatric age group. The rate of involvement of the left and right side of the body was $57.8 \%$ and $42.2 \%$, respectively. In female patients, involvement was on the left side in $59.7 \%$ and on the right side in $40.3 \%$ of them; in male patients, involvement was on the left side in $63.2 \%$ and on the right side in $36.7 \%$ of them.

The most frequent triggering factor was emotional stress in both adult and pediatric groups. Upper and lower respiratory tract infections, fatigue and surgical operation were the other triggering factors (Table 2).

The most frequent complication was postherpetic neuralgia (PHN) (27.7\%). Ophthalmic HZ was observed in 8 adults (5.2\%), and 2 of pediatric group (15.4\%). All patients with ophthalmic $\mathrm{HZ}$ were treated with systemic antiviral treatment, examined by an ophthalmologist and ophthalmic complication was not observed. No other complications,

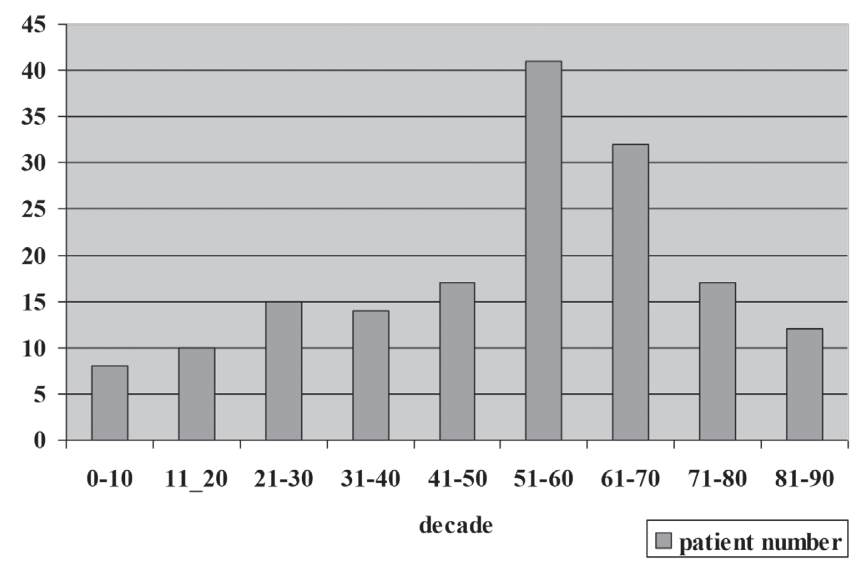

Figure 1. Number of patients according to decades

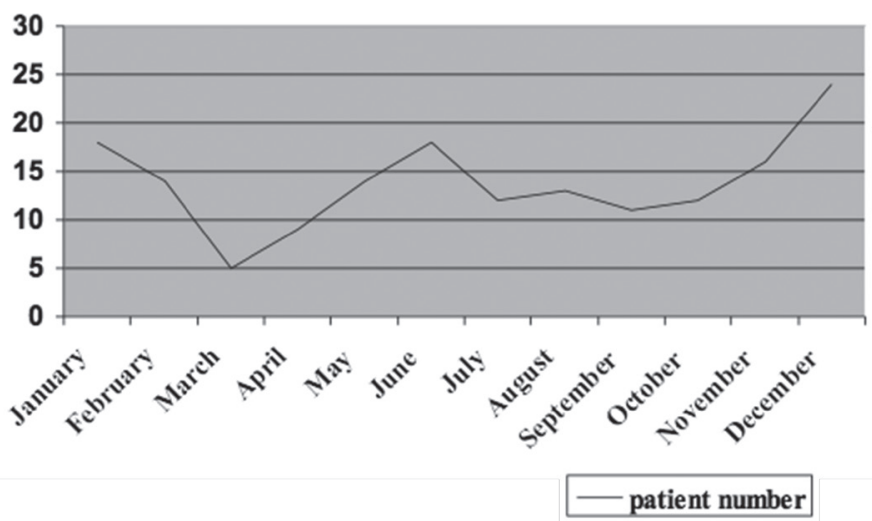

Figure 2. Number of patients according to months 


\begin{tabular}{|c|c|c|}
\hline & $\mathrm{n}$ & $\%$ \\
\hline Thoracic & 76 & 45.8 \\
\hline Lumbal & 40 & 24.1 \\
\hline Lower extremity & 17 & 10.2 \\
\hline Upper extremity & 15 & 9.0 \\
\hline Trigeminal & 10 & 6.0 \\
\hline Cervical & 5 & 3.0 \\
\hline Sacral & 3 & 1.8 \\
\hline Total & 166 & 100 \\
\hline
\end{tabular}

Table 2. Trigger factors

\begin{tabular}{|l|l|l|}
\hline & $\mathbf{n}$ & $\%$ \\
\hline Emotional stress & 35 & 21.0 \\
\hline Upper respiratory tract infection & 19 & 11.4 \\
\hline Fatigue & 18 & 10.8 \\
\hline Surgical operation & 1 & 0.6 \\
\hline Lower respiratory tract infection & 1 & 0.6 \\
\hline Total & 74 & 44.4 \\
\hline
\end{tabular}

such as disseminated $\mathrm{HZ}, \mathrm{HZ}$ oticus, and VZV meningitis, were observed in any patient.

In respect of accompanying systemic diseases, at least one systemic disease was present in $54.8 \%$ of patients. The most frequently seen systemic diseases were hypertension (HT) (27.1\%), diabetes mellitus (DM) $(18.1 \%)$ and coronary artery disease (CAD) (15.1\%) (Table 3). Malignancy was detected in only 3 patients (1.8\%); these were breast, lung and stomach cancers. No complication, accompanying systemic disease or malignancy were detected in the pediatric age group.

In respect of treatment, 53\% of patients were treated with valacyclovir, $29.5 \%$ with brivudine and $2.4 \%$ with acyclovir; systemic antiviral treatment was not administered in $15.1 \%$ of patients. In pediatric group, $61.5 \%$ of patients did not receive systemic antiviral treatment. Only 5 patients with ophthalmic $\mathrm{HZ}$ required hospitalization. No drugrelated side effect was observed in patients treated with systemic antiviral treatment.

\section{Discussion}

$\mathrm{HZ}$ occurs by reactivation of VZV remaining latent at dorsal root ganglia following chickenpox at later stage of life and seen as painful vesicular lesions on dermatomes innervated by these ganglia ${ }^{3}$.

Annual incidence of $\mathrm{HZ}$ is $3.2 / 1000^{4}$ and $4.97 / 1000^{5}$ in the United States and Taiwan, respectively; and studies conducted in our country reported an incidence of 5.6 and $4.3 / 1000^{6,7}$. In our study, HZ was diagnosed in $0.68 \%$ of patients admitted during this period ( 24125 patients) $\mathrm{HZ}$ mostly occurs at advanced age. The incidence of $\mathrm{HZ}$ increases with age due to decreased humoral and cellular immunity. A study showed that the incidence of $\mathrm{HZ}$ increased by aging and it was detected as 5.18/1000, 8.36/1000, 11.09/1000 and 11.77/1000 at 40 to 50 years, 50 to 60 years, 60 to 70 years and over 70 years, respectively ${ }^{5}$. Küçükçakır et al. ${ }^{6}$ showed that $72.1 \%$ of patients were
Table 3. Accompanying systemic diseases

\begin{tabular}{|l|l|l|}
\hline & $\mathbf{n}$ & $\%$ \\
\hline HT & 45 & 27.1 \\
\hline CAD & 30 & 18.0 \\
\hline Asthma & 25 & 15.0 \\
\hline Hyperlipidemia & 5 & 3.0 \\
\hline Chronic renal failure & 5 & 3.0 \\
\hline Malignancy & 5 & 3.0 \\
\hline Hepatitis B & 3 & 1.8 \\
\hline Hypothyroidism & 3 & 1.8 \\
\hline Epilepsy & 3 & 1.8 \\
\hline Gastritis & 3 & 1.8 \\
\hline Hyperthyroidism & 2 & 1.2 \\
\hline Gilbert & 2 & 1.2 \\
\hline Benign prostatic hypertrophy & 2 & 1.2 \\
\hline Depression & 2 & 1.2 \\
\hline Pregnancy & 2 & 1.2 \\
\hline Hepatosteatosis & 2 & 1.2 \\
\hline Chronic obstructive pulmonary disease & 1 & 0.6 \\
\hline Liver cirrhosis & 1 & 0.6 \\
\hline HT: Hypertension, DM: Diabetes mellitus, CAD: Coronary artery disease & \\
\hline
\end{tabular}

over 40 years of age and that most of the patients were in the $6^{\text {th }}$ and $7^{\text {th }}$ decades of life. Similarly, most of the patients in our study were in the $6^{\text {th }}$ and $7^{\text {th }}$ decades of life.

$\mathrm{HZ}$ is known to affect equally both sexes and all races ${ }^{3}$. Certain studies suggested that $\mathrm{HZ}$ incidence was remarkably higher in women ${ }^{4,5,8-11}$. Similarly, in our study, we detected that $\mathrm{HZ}$ was more frequent in women. However, there are studies reporting more frequent occurrence in men ${ }^{7,12}$.The relationship between $\mathrm{HZ}$ and sex is not clear. It can be explained by immune system differences between male and females; and it is more likely that the virus becomes more active in the female body than in male ${ }^{8,9}$.

Zak-Prelich et al. ${ }^{12}$ observed $\mathrm{HZ}$ more frequently during summer time on sun-exposed areas, while they did not detect any seasonal difference in non-exposed body areas. When all cases were analyzed, the disease was detected most frequently in August. Therefore, they suggested that ultraviolet radiation suppressed cellular immunity in summer and it resulted in increased $\mathrm{HZ}$ incidence ${ }^{12}$. In large series of studies, $\mathrm{HZ}$ was detected mostly in summer and least in winter ${ }^{8,13}$. A study from our country observed $\mathrm{HZ}$ mostly in March and in winter season ${ }^{7}$. In contrast to these studies; we detected that $\mathrm{HZ}$ was most frequent in winter, was least frequent in spring compared to the other seasons and $\mathrm{HZ}$ was most frequent in December, was least frequent in March compared to the other months. Küçükçakır et al. ${ }^{6}$ indicated that $\mathrm{HZ}$ was most frequent in August and January and they suggested that the reason of increased cases in January was suppression of immunity by decreased weather temperature. Further studies with larger number of patients are required in order to demonstrate seasonal difference of $\mathrm{HZ}$ in our country. 
Lesions are mostly located on dermatomes, unilaterally, without passing the midline in $\mathrm{HZ}^{3}$. Küçükçakır et al. ${ }^{6}$ observed more common involvement on the left side in women and right side in men. Another study did not show any difference between left or right-side involvement in respect of $\mathrm{HZ}$ lesion localization ${ }^{8}$. Differently, we detected that involvement was more frequent on the left side in both men and women. The most frequent involvement of $\mathrm{HZ}$ was in the thoracic region ${ }^{2,3}$. Previous studies showed that the most frequent involvements were on thoracic, lumbar, trigeminal and cervical areas ${ }^{6-8}$. Similarly, the most frequent involvements were on thoracic and lumbar areas in our study. In studies in the pediatric age group, the most frequent involvement was also again in the thoracic region ${ }^{6,14-16}$. In agreement with the literature, the most frequent involvement was also again in the thoracic region (53.8\%) in the pediatric age group in our study.

Stress, fever, sunburn, physical trauma to the spinal cord, radiotherapy, immunosuppressive therapy, cancer, HIV infection, heavy metal intoxication and re-exposure to VZV are among the triggering factors ${ }^{3}$. Stress and trauma have been reported to be the most common triggers ${ }^{7,14}$. Chronic psychological stress is considered to facilitate $\mathrm{HZ}$ development by reducing cellular immune response ${ }^{17}$. We detected stress as the most frequent triggering factor in both adult and pediatric age groups.

$\mathrm{PHN}$ is defined as continuation of pain for more than a month on the affected dermatome following improvement of $\mathrm{HZ}$ and this is the most frequent complication of $\mathrm{HZ}$. The most important risk factor for $\mathrm{PHN}$ is advanced age. The risk of developing PHN has been reported to range from $5 \%$ to $30 \%{ }^{18}$. It has been reported that PHN developed most frequently in patients over 80 years of age ${ }^{10}$. Alicino et al. ${ }^{11}$ reported that PHN was remarkably increased with age and reached to peak at age over 85 years. In their studies from our country, Küçükçakır et al. ${ }^{6}$ and Özkol et al. ${ }^{7}$ reported that the risk of PHN development was $21.75 \%$ and $13 \%$, respectively. We detected this rate as $27.7 \%$. The reason for lower PHN rate observed in the second study compared to our study could be lower mean age of patients. PHN is less frequent in the pediatric age group. PHN was not observed in the pediatric age group in studies from our country and other countries $6,14,16,19$. Similarly, we also did not detect PHN in the pediatric age group.

It is known that $\mathrm{HZ}$ is often accompanied by malignancies. Küçükçakır et al. ${ }^{6}$ found malignancy in $3.84 \%$ of $\mathrm{HZ}$ patients and the disease was not considered to antecede any malignancy. In another study, malignancy was detected in $1.7 \%$ of patients ${ }^{20}$. In our study, a history of malignancy was present in $1.8 \%$ and all the cases had been diagnosed with cancer before $\mathrm{HZ}$. In a meta analysis, absolute risk for occurrence of any cancer within 1 year following $\mathrm{HZ}$ was $0.7-1.8 \%$ and this risk was relatively high for hematological cancers. The authors suggested that $\mathrm{HZ}$ could be an indicator for occult cancer, however, the low absolute risk of cancer limits the clinical impact of this study ${ }^{21}$. However, the possibility of malignancy in $\mathrm{HZ}$ patients should always be kept in mind and detailed examination should be performed in suspected cases. $\mathrm{HZ}$ is rare during childhood. In case of $\mathrm{HZ}$ occurrence during childhood, this may indicate more serious conditions such as immunosuppression and malignancy. However, majority of children diagnosed with $\mathrm{HZ}$ are healthy in other aspects ${ }^{3}$. In our study, no malignancy was detected in the pediatric patients.
In the literature, it has been reported that HT, DM, hyperlipidemia and cardiac diseases mostly accompanied by $\mathrm{HZ}^{6,8,10}$. This may show that these conditions could trigger $\mathrm{HZ}$ by impairing cellular and humoral immunity ${ }^{6}$. Similarly, in our study, most frequently accompanying diseases were HT, DM and CAD. We consider that the reason can be impairment of cellular and humoral immunity by these conditions as well as frequent occurrence of $\mathrm{HZ}$ and these diseases at advanced age. Acyclovir, valacyclovir, famciclovir and brivudin are systemic antiviral drugs used in the treatment of $\mathrm{HZ}$. We found that valacyclovir was the most preferred drug in adults. In this study, systemic antiviral treatment was not administered in some adult patients with mild disease, no pain, and late diagnosis. Routine systemic antiviral treatment is not recommended in healthy children due to mild nature of $\mathrm{HZ}$ and rare occurrence of post-herpetic neuralgia ${ }^{3}$. In our study, the majority of pediatric patients (61.5\%) were monitored without systemic treatment; and the most frequently preferred systemic agent was acyclovir. No drug-related side effect was observed in patients treated with systemic antiviral treatment.

\section{Study Limitation}

The single-centered design of this study constitutes a limitation of our study.

\section{Conclusion}

Our data are highly comparable with other studies. However, occurrence of $\mathrm{HZ}$ mostly in winter and left side of the body were the differences between our results and those of other studies. We conclude that further nation-wide studies with higher number of patients are needed in order to clarify the epidemiological and clinical characteristics of $\mathrm{HZ}$ in our country.

\section{Ethics}

Ethics Committee Approval: Ahi Evran University Lochal Ethics Committee (approval number: 2017-09/76, 23.05.2017).

Informed Consent: Informed consent form was obtained from all the patients included in this study.

Peer-review: Externally peer-review.

\section{Authorship Contributions}

Surgical and Medical Practices: E.A., H.K.E., I.B., E.M.A., Concept: E.A., H.K.E., I.B., E.M.A., Design: E.A., H.K.E., I.B., E.M.A., Data Collection or Processing: E.A., H.K.E., I.B., E.M.A., Analysis or Interpretation: E.A., H.K.E., Literature Search: E.A., Writing: E.A.

Conflict of Interest: No conflict of interest was declared by the authors.

Financial Disclosure: The authors declared that this study received no financial support.

\section{References}

1. Cohen J: Clinical practice: Herpes zoster. N Engl J Med 2013;369:255-63

2. Coşkun BK, Çiçek D: Insan Herpes Virüsleri, Dermatoloji' de. Ed. Sarıcaoğlu H, Başkan EB. Bursa, Nobel Tıp Kitapevi 2012:1204-8.

3. Öztürkcan S: Herpes zoster (Zona, Gece Yanığı). Dermatoloji' de. Ed. Tüzün Y, Gürer MA, Serdaroğlu S, Oğuz O, Aksungur VL: 3.Baskı. İstanbul, Nobel Tıp Kitapevi 2008:607-14. 
4. Insinga RP, Itzler RF, Pellissier JM, Saddier JM, Nikas AA: The incidence of herpes zoster in a United States administrative database. J Gen Intern Med 2005;20:748-53.

5. Lin $\mathrm{YH}$, Huang LM, Chang IS, et al: Disease burden and epidemiology of herpes zoster in pre-vaccine Taiwan. Vaccine 2010;28:1217-20.

6. Küçükçakır $\mathrm{O}$, Aliağaoğlu $\mathrm{C}$, Turan $\mathrm{H}$, et al: Retrospective evaluation of patients with herpes zoster followed up in our department between 19992010. Turkderm 2012;46:186-90.

7. Özkol HU, Bilgili SG, Karadağ AS, Altun F, Çalka Ö: The Evaluation Clinical and Demographic Characteristics of 115 Patients Diagnosed with Herpes Zoster in Eeastern Turkey. Turk J Dermatol 2013;7:201-5.

8. Jung HS, Kang JK, Yoo SH: Epidemiological study on the incidence of herpes zoster in nearby cheonan. Korean J Pain 2015;28:193-7.

9. Fleming DM, Cross KW, Cobb WA, Chapman RS: Gender difference in the incidence of shingles. Epidemiol Infect 2004;132:1-5.

10. Takao Y, Miyazaki Y, Okeda M, et al: Incidences of herpes zoster and postherpetic neuralgia in japanese adults aged 50 years and older from a community-based prospective cohort study: the shez study. J Epidemiol 2015;25:617-25.

11. Alicino C, Trucchi C, Paganino C, et al: Incidence of herpes zoster and postherpetic neuralgia in Italy: Results from a 3-years population-based study. Hum Vaccin Immunother 2017;13:399-404.

12. Zak-Prelich $M$, Borkowski JL, Alexander $F$, Norval M: The role of solar ultraviolet irradiation in zoster. Epidemiol Infect 2002;129:593-7.
13. Toyama N, Shiraki K; Society of the Miyazaki Prefecture Dermatologists: Epidemiology of herpes zoster and its relationship to varicella in Japan: A 10-year survey of 48,388 herpes zoster cases in Miyazaki prefecture. J Med Virol 2009;81:2053-8.

14. Çölgeçen E, Küçük Ö, Balcı M: Clinical Features of Herpes Zoster Infections in Childhood. Turkderm 2012;46:26-8.

15. Takayama N, Yamada H, Kaku H, Minamitani M: Herpes zoster in immunocompetent and immunocompromised Japanese children. Pediatr Int 2000;42:275-9.

16. Katakam BK, Kiran G, Kumar U: A prospective study of herpes zoster in children. Indian J Dermatol 2016;61:534-9.

17. Sen S, Bayram N, Bal ZS, et al: Herpes zoster experience in two pediatric infection clinics. Turk Arch Ped 2013;48:40-3.

18. Kawai K, Gebremeskel BG, Acosta CJ: Systematic review of incidence and complications of herpes zoster: towards a global perspective. BMJ Open 2014:4:e004833.

19. Tepe B, Bucak iH, Almış H: Herpes Zoster in Healthy Children: A Retrospective Study. Turk J Dermatol 2016;10:65-9.

20. Ertunç $V$, Dane Ş, Çolak $A$, et al: Relations of age, sex, distribution and associated diseases with herpes zoster. Journal of Turgut Özal Medical Center 1997:4:29-32.

21. Schimdt SA, Mor A, Schonheyder HC, Dekkers OM, Cronin-Fenton D: Herpes zoster as a marker of occult cancer: A systematic review and meta-analysis. J Infect 2017;74:215-35. 